\title{
Tezyînî kitap sanatları konulu Türkçe bibliyografyalar üzerine bir değerlendirme
}

\section{Gülnihal KÜPEL'ं1}

\begin{abstract}
APA: Küpeli, G. (2020). Tezyînî kitap sanatları konulu Türkçe bibliyografyalar üzerine bir değerlendirme. RumeliDE Dil ve Edebiyat Araştırmaları Dergisi, (18), 350-361. DOI: $10.29000 /$ rumelide.705771
\end{abstract}

\section{$\ddot{\mathbf{O} z}$}

Türk-İslam kitap sanatları (minyatür, tezhip, katı', cild) konusunda Türkçe ortaya konulan bazı araştırmaların, gerek bezemeli yazmaların akademik câmiâya ilk kez tanıtılması gerekse de bu sanatlara ilişkin teorik arka planın oluşturulup, kavramsal içeriğin belirlenmesi hususunda Batı'daki yayınlara dahi önayak olduğu bir gerçektir. Buna rağmen, tezyînî kitap sanatlarını konu alan Türkçe bibliyografyaların tarihi en iyi ihtimalle 1969 yılına kadar geri götürülebilir. Bu tarihten günümüze uzanan 50 yıllık serüvenini köşe taşlarını üç kitap, beş makale ve bir tez çalışması oluşturmaktadır. Bu makalede, ilgili bibliyografyaların temel özellikleri dönem ve format itibariyle tanıtılacak, ihtiva ettikleri künyelerin yayın dili ve konuları üzerinden bir takım değerlendirmelere gidilecektir. 19272019 yılları arasında Latin alfabesiyle hazırlanan Türkçe çalışmalara ilişkin istatistiklere bakılırsa, alanla ilgili ilk bibliyografik makale İ. Binark, ilk bibliyografik kitap ise N. Atasoy tarafindan hazırlanmıştır. Yayınlanan üç kitaptan ilk ikisi minyatür eksenli olup, seçilmiş bibliyografya özelliği taşırken, doğrudan minyatür, tezhip, katı' ve cild konulu Türkçe yayınlara odaklanan kitap çalışması ancak 2019 yılında ortaya konmuştur. Bütün bunlara ilaveten makalede, tezyînî kitap sanatları konulu Türkçe çalışmalar, ansiklopedi maddeleri ve lisansüstü tez çalışmaları bağlamında ele alınarak bazı değerlendirmelere de yer verilecektir.

Anahtar kelimeler: Türk-İslam kitap sanatları, minyatür, tezhip, katı', cild, bibliyografya.

\section{An evaluation on The Turkish bibliographies about the arts of the decorated books}

\begin{abstract}
It is a fact that some researches in Turkish on Turkish-Islamic book arts (painting, illumination, qatı', bookbinding) leads even to the publications in the West both in the context of introducing varied decorated manuscripts to the academic community for the first time and establishing theoretical background of these arts and determining their conceptual content. But the history of bibliographies in Turkish on the arts of the book can be traced back to 1969 at best. The cornerstones of its 50-year adventure dating back to this day are the three books, five articles, and a dissertation.In this article, the basic features of the related bibliographies will be introduced in terms of period and format, and some evaluations will be made on the tags through their publication language and topics. If we look at the statistics about Turkish publications prepared with Latin alphabet between 1927-2019, the first bibliographic article related to the field belongs to I. Binark and the first bibliographic book was prepared by N. Atasoy. The first two of three books are focused on the art of miniature painting with the feature of the selected bibliography. The book, which focused directly on publications in Turkish
\end{abstract}

1 Dr. Öğr. Üyesi, Marmara Üniversitesi, Güzel Sanatlar Fakültesi, Geleneksel Türk Sanatları Bölümü (İstanbul, Türkiye), gulnihalkupeli@gmail.com, ORCID ID: 0000-0002-2055-0427 [Makale kayit tarihi: 20.02.2020-kabul tarihi: 20.03.2020; DOI: 10.29000/rumelide.705771] 


\begin{abstract}
about miniature painting, illumination, bookbinding, and qatı' was only published in 2019.In addition to all of these, the Turkish studies on the arts of the decorated manuscripts will be discussed through the encyclopedia articles and postgraduate dissertations and some evaluations will also be made on this issue.
\end{abstract}

Keywords: Turkish-Islamic book arts, painting, illumination, qatı', bookbinding, bibliography.

Geleneğimizdeki tabiriyle "esâme-i kütüp" veya "fihrist" diyebileceğimiz bibliyografya çalışmaları, bilimsel araştırmaların belirli bir konu ve faydalı bir amaç odaklı gerçekleştirilmesi adına oldukça önemlidir. Araştırma konusunun sınırlarının doğru tespit edilip içeriğin zenginleştirilmesine hizmet eden bu tür yayınlar, tekrarların önlenmesinde, dolayısıyla mevcut bilgilerden beslenen yeni bulguların ortaya çıkarılmasında müstesna rol oynamaktadır. Yeni sayılan şeylerin bir kısmı iyice unutulmuş eskiler olduğuna göre söz konusu eskileri sürekli hatırlamamızı sağlayan bibliyografyalar, akademik araştırmalarımızdaki kısır döngüyü engelleyen bilimsel kontrol mekanizmasının gerekli bir dişlisi niteliğindedir. Bu bakımdan bibliyografik çalışmalara her alanda duyulan ihtiyaç, Türk-İslam kitap sanatları gibi ihmal edilen bilim dallarında daha fazla hissedilmektedir.

Tezyînî kitap sanatları alanında Türkiye'de yapılan bibliyografyaların tarihini en iyi ihtimalle 1960'ların sonuna kadar geri götürmek mümkündür. İsmet Binark’ın 1969 yılında kaleme aldığı Türk Vakıfları, Türk Sanatı ve İçtimâ̂ Hayat Konusu ile İlgili Eserlerin Bibliyografyası isimli makalesi bu türden çalışmaların en erken örneklerindendir (Binark,1969, ss.357-366). Daha ziyade Türk-İslam sanatlarının geneline odaklanan bu çalışma, muhtevasının eksikliğine rağmen hem ilk denemelerden olması hem de araştırmacının 1973 yılında çıkardı̆̆ı Türk Dekoratifve Resim, Seramik Örme ve İşleme, Heykeltraşllk, Oymacılık Meskükât ve Maden Sanatları Bibliyografyası isimli daha geniş makalesinin (Binark, 1973, ss. 463-478). ilk taslağını oluşturması hasebiyle önemli bir konuma sahiptir. İkinci makalede Türkiye'de yayınlanan hat, tezhip, minyatür ve cilt konulu çalışmaları kuşatmaya çalışan İ. Binark, yayın künyelerini "dekoratif sanatlar" ve "resim sanatı" başlıkları altında alfabetik olarak sıralamıştır. Makalenin girişinde belirtildiği üzere 1928-1971 yllarına ait kitaplar ağırlıklı olarak Türkiye Bibliyografyası'na, 1952-1971 tarihli yayınları içeren makaleler ise Türkiye Makaleler Bibliyografyası'na göre tespit edilmiştir. Bazı istisnalar hâriç, Türkçe kaleme alındıkları anlaşılan eserlerin toplam sayısı 369 olup, bunlardan 141’i minyatür sanatıyla ilgilidir.

Alanla ilgili literatürün kitap formatında tanıtıldığı ilk Türkçe çalışma, Nurhan Atasoy’un 1972 yılında yayınladığı Türk Minyatür Sanatı Bibliyografyası adlı eseridir (Atasoy, 1972). Tercih edilen yayın formatının yanı sıra N. Atasoy'un çalışmasını İ. Binark'ın makalelerinden ayıran iki önemli içerik farklılığı daha bulunmaktadır. Bunlardan ilki, kitap sanatlarıyla ilgili eserleri sadece minyatür ekseninde ele alması, ikincisi ise Türkçe kaynaklardan ziyade yabancı literatüre odaklanmasıdır. Kitapta alfabetik olarak sıralanan takriben 350 makale, bildiri ve kitap künyesinden 124'ü Türkçe iken geri kalanı İngilizce, Fransızca ve Almancadır.

Türk-İslam kitap sanatlarına karşı çeşitli sebeplerden dolayı ilgisizliğin hüküm sürdüğü yıllarda kaleme alınmış olması, İ. Binark'ın makaleleri gibi N. Atasoy'un kitabına da müstesna bir önem kazandırmaktadır. Önsöz'de, minyatür sanatını "Doğu tasvir sanatının en önemli kolu" olarak nitelendiren yazar, Türk minyatür sanatı tarihini inceleyen kapsamlı çalışmaların 1960'lı yıllardan itibaren yayınlandığına dikkat çekmiş; alanla ilgili bibliyografya hazırlamanın güçlüklerinden bahsederek olası noksanların meslektaşları tarafından giderilmesi hususunda mütevazı bir temennide bulunmuştur. 
Sadi Bayram'ın 1994 yılında yayınladığı Türk Hat, Yazı-Resim, Cilt, Tezhip ve Minyatür Sanatı ile İlgili Seçilmiş Bibliyografya isimli çalışmasını bir bakıma bu temenniden doğan olumlu bir sonuç olarak ele alabiliriz (Bayram, 1994, ss.321-342). Yayın formatı ve biçim itibarıyla İ. Binark'ı takip eden S. Bayram'ın içerik konusundaki tercihi N. Atasoy'dan yanadır. Diğer bir ifadeyle, kitap sanatlarının genelini ele alıp minyatür çalışmalarını özel bir başlık altında sıralaması İ. Binark’ın, Türkçe kaynaklarla birlikte yabancı yayınlara yer vermesi ise N. Atasoy'un yöntemini anımsatmaktadır. Neticede toplam 936 künyeyi ihtiva eden bu çalışmadaki Türkçe kaynak sayısı 377 olup, bunlardan 190’ı minyatür konuludur.

Tezyînî kitap sanatlarımızla ilgili bibliyografya denemelerinin seyri 200o'li yıllara kadar böyle cereyan ederken, bu tarihten itibaren nispeten daha kapsamlı üç çalışmanın yapıldığı görülmektedir. Bunlardan birincisi, Şeyda Memili’nin yüksek lisans tezi çerçevesinde ortaya koyduğu Türk Kitap Sanatları Bibliyografyası isimli çalışmasıdır (Memili, 2007). Önsöz'den anlaşıldı̆̆ı üzere İ. Binark ile S. Bayram'ın makaleleri ışı̆̆ında geliştirilen çalışmanın temel amacı; hüsn-i hat, minyatür, tezhip, cild, ebru ve katı' sanatlarıyla ilgili olup, 1923-2007 yllarına tarihlenen kitap, makale, ansiklopedi maddesi, lisansüstü tez, katalog ve bildiri türünden bütün Türkçe literatürün kuşatılmasıdır. Bu hedef doğrultusunda söz konusu sanat dalları müstakil bölümler halinde ele alınmakta, her birinin tarihçesine dair kısaca bilgi aktarıldıktan sonra ilgili kaynak künyeleri sıralanmaktadır. Ne var ki amaç ve genel düzen itibarıyla izlenen bu doğru bakış açısının, kitap sanatlarıyla ilgili teorik kısımlardaki eksik genellemelerin ve bibliyografya bölümlerindeki ciddi yöntem hatalarının gölgesinde kaldığını belirtmek zorundayız. Daha açık ifade etmek gerekirse çalışmanın problemi ile amacı, evreni ile örneklemi arasında orantılı bir bağ kurulmamış, veriler doğru ve kuşatıcı bir yönteme göre elde edilmediği gibi herhangi bir analize de tabi tutulmamıştır. Kastettiğimiz yöntem eksikliğinin en bariz örneği, bibliyografik künyelerin Ankara, İstanbul, Eskişehir ve Kayseri sınırları içerisindeki bazı kütüphanelere göre alınmış olmasıdır. Söz konusu kütüphanelerin hangi kıstaslara göre seçildiği temellendirilmemiş, bu eksikliğin 'online' arama motorları üzerinden sistemsiz biçimde kapatılma çabası daha karmaşı hatalar zincirini doğurmuştur. Örneğin, kütüphane kayıtları doğru kabul edildiği için eser içerikleri kontrol edilmemiş ve künyesi yanlış kaydedilen çalışmalar farklı yayınlar olarak alınmıştır. Yine kütüphane kataloglarında bulunmamaları hasebiyle tez çalışmalarının büyük bir kısmı gözden kaçırılmış; doğrudan İslam sanatlarıyla ilgili olmayan bazı eserler ve internet sitelerindeki genel kültür yazıları literatüre eklenmiş; başlıklardaki benzerlik dolayısıyla mimarî tezyînat, metal ve kumaş süslemesi gibi farklı alanlara ilişkin çalışmalara da yer verilmiştir. Gerek nicelik gerekse de nitelik itibarıyla tez çıtılarının güvenilirliğine yönelik ciddi soru işaretleri oluşturan bu ve benzeri eksikliklerden dolayı söz konusu çalışmanın mevcut boşluğu doldurmak yerine daha çetrefilli bir hale soktuğunu söylemek mümkündür.

Yakın dönemde gerçekleştirilen bir diğer çalışma, Mert Ağaoğlu ile Ömer Çepnioğlu'nun ortak imzalarını taşıyan Osmanlı Minyatür Sanatı Bibliyografyası'dır. İki ayrı makale olarak yayımlanan bu bibliyografyanın birinci kısmında kitap ve tez künyelerine, ikinci kısmında ise makale ve ansiklopedi maddelerine yer verileceği, dolayısıyla da bildirilerin ve yabancı yayınların dışarıda tutulacağı belirtilmektedir (Ağaoğlu ve Çepnioğlu, 2014, ss.165-174; 2015, ss.95-104). Çalışmayı öncekilerden farklı kılan bir diğer özellik ise Osmanlı minyatür sanatını konu alan Türkçe literatüre odaklanmasıdır. Fakat listedeki eserler arasına bazı matbu bildirilerin ve Türkiye'de yabancı dillerde basılan yayınların da alındığı görülür. İlk makalenin girişi mahiyetindeki kısa notta Türkiye'deki bibliyografya çalışmalarının yetersizliğine dikkat çeken M. Ağaoğlu, literatür tespitinde izledikleri yönteme ve kullandıkları kaynaklara dair açıklamada bulunmadığı gibi ilgili literatürün kapsamı ve içeriği konusunda herhangi bir değerlendirme de yapmamıştır. Nurhan Atasoy'un kitabının yegâne minyatür 
bibliyografyası olarak takdim edildiği ve yukarıda bahsi geçen diğer çalışmaların dikkate alınmadığı bu deneme, seçilmiş bibliyografya niteliğinde olup, 54'ü kitap, 79'u tez, 159'u ise makale, bildiri ve ansiklopedi maddesi olmak üzere toplam 292 Türkçe yayın künyesini içermektedir.

Türkiye'de tezyînî kitap sanatları konusunda yapılan bir diğer bibliyografya çalışması, Elif Kök'ün 2016 yılında yayınlanan Türk ve İslâm Sanatı Minyatür Bibliyografyası isimli kitabıdır (Kök, 2016). Sunuş, giriş, beş bölüm ve dizin kısımlarından oluşan çalışmayı, N. Atasoy’un kitabının güncel kaynaklarla zenginleştirilmiş şekli olarak değerlendirmek mümkündür. Nitekim bu eseri temel hareket noktası olarak alan yazar, "aradan geçen 44 yılın birikimini” yerli ve yabancı kaynakları tarayarak tamamlamaya gayret göstermiştir. Kısa Giriş’in (s. 9-11) ardından, yayın künyelerini "genel bibliyografya" başlığı altında (s. 13-175) alfabetik olarak sıralamış, daha sonra ise aynı künyeleri "bibliyografyalar", "koleksiyon, envanter ve kataloglar", "bölgeler ve kültür çevreleri”, "işlenen konular" şeklindeki alt başlıklarına göre tekrar tasnif etmiştir (s. 177-299). Kitabın sonunda kısa bir "dizin"e yer verilmiştir (s. 301-303). Bu kısma yazar ve kavram dizininin de eklenmesi kullanıcılara kolaylık sağlanması adına faydalı olabilirdi.

Giriş’ten anlaşıldığı kadarıyla çalışmanın içeriğini şekillendiren yabancı kaynaklar genel itibarıyla K.A.C. Creswell'in A Bibliyography of Painting in Islam adll eserinden (Archibald ve Creswell, 1953; 1974), Susan Sinclair’in editörlüğ̈̈nde çlkan Bibliography of Art And Architecture in The Islamic World isimli iki ciltlik kapsamlı bibliyografya çalışmasından (Sinclair, 2012) ve dijital veri tabanı olan Index Islamicus'tan oluşmaktadır. Öte taraftan Türkçe kaynaklar hakkında açıklama yapılmamış, Türkçe dergilere ulaşmanın zorluğuna değinen yazar, başlıca periyodiklerin tarandığını belirtmekle yetinmiştir. N. Atasoy'un kitabı hâriç tutulursa, daha önce yapılan bibliyografya çalışmaları hakkında bilgi aktarılmamış ve içerik analizine gidilmemiştir. Giriş’te zikredilmese de İ. Binark’nn ve S. Bayram'ın makalelerinin bibliyografyaya dâhil edilmesi bu yayınların E. Kök tarafından bilindiğini göstermektedir. M. Ağaoğlu ve Ö. Çepnioğlu'nun makaleleri ile Ş. Memili'nin tezinin ilgili literatür arasına alınmamasının ise bilinçli bir tercihten kaynaklanmış olması kuvvetle muhtemeldir. Zira yazarın amacının, tezyînî kitap sanatlarımızla ilgili bütün literatürü değil, sadece minyatür konulu en temel eserleri içeren seçilmiş bir bibliyografya hazırlamak olduğu aşikârdır. Bu hedef doğrultusunda Türkİslam minyatür sanatı üzerine araştırmalarıyla tanınan en önemli isimler tespit edilmiş ve belirli araştırmacıların önemli eserlerini ihtiva eden faydalı bir kaynakça oluşturulmuştur. Kitabın içeriğinin daha ziyade yabancı kaynaklara göre şekillendirilmesinin ve Türkiye'de minyatür üzerine yapılan makale, ansiklopedi maddesi ve tez çalışmaların büyük bir kısmının dışarıda tutulmasının nedeni de bu olmalıdır. Nitekim künyeleri zikredilen Türkçe literatürün toplam sayısı 450 civarındadır ki bu rakam mevcut kaynakların \%30'unu dahi yansıtmamaktadır.

Yukarıda bahsi geçen yayınları, Türkiye'de kitap tezyînatı konulu bibliyografya çalışmalarının 50 yıllık tarihi serüvenindeki birer köşe taşı olarak kabul etmek mümkündür. İki kitap, beş makale ve bir tez çalışmasından oluşan bu bibliyografları ana hatlarıyla değerlendirecek olursak, iki temel özelliğin öne çıktığını görebiliriz: Birincisi, çalışmaların büyük bir kısmı minyatür eksenli olup tezhip, katı’ ve cild gibi diğer kitap bezeme sanatlarını ya kısmen içermekte ya da hiç içermemektedir. İkincisi, söz konusu bibliyografyalarda zikredilen eserlerin büyük çoğunluğu İngilizce başta olmak üzere çeşitli Batı dillerindeki kitap, makale ve bildirilerden oluşmaktadır. Hâlbuki daha önce de değindiğimiz gibi Batılı araştırmacılar tarafından bu çalışmaları sistematik biçimde listeleyen kapsamlı bibliyografyalar zaten hazırlanmıştır. 
Türk-İslam kitap sanatlarına ilişkin derinlemesine bir araştırmada, yabancı kaynaklara nüfuz etmek günümüzün akademik zorunluluklarındandır. Fakat bu sanatların müstesna gelişimi Batı'da gerçekleşmediği gibi, alanla ilgili bütün ciddi yayınlar da Batı dillerinde hazırlanmış değildir. Aksine Türkçe ortaya konulan pek çok araştırma, gerek bazı bezemeli yazmaların akademik câmiâya ilk kez tanıtılması gerekse de bu sanatlara ilişkin teorik arka planın oluşturulup, kavramsal içeriğin belirlenmesi hususunda Batı'daki yayınlara dahi önayak olmuştur. Dolayısıyla, geleneğimizin ifadesi olan tezyînî kitap sanatlarımız hakkındaki Türkçe literatürün listelenip boşlukların ortaya konulması; bu sanatların tetkîkine yönelik akademik mirasımızın artı ve eksi yönlerinin en azından literatür olarak belirlenmesi büyük önem arz etmektedir.

Gülnihal Küpeli’nin imzasını taşıyan Tezyînî Kitap Sanatları Türkçe Yayınlar Bibliyografyası adlı eser (Küpeli, 2019) söz konusu eksikliği kısmen de olsa giderme çabasıyla yayına hazırlanmıştır. Alanla ilgili en son Türkçe bibliyografya özelliği taşıyan bu çalışmada yukarıda özet olarak belirtilen hususlar doğrultusunda dört temel amaç gözetilmiştir:

1. Türkçede tezyînî kitap sanatları (tezhip, minyatür, katı' ve cild) konusunda yapılan çalışmaların tam künyelerinin belirlenip sistematik olarak listelenmesi, böylelikle de kitap tezyînatı konusundaki Türkçe yayınlarda hangi konulara odaklanıldığının ve hangi konuların eksik çalışıldığının kaynakça zemininde tespit edilmesi;

2. Tezyînî kitap sanatları (tezhip, minyatür, katı’ ve cild) alanında bütün yeni fikirlerin Batılı araştırmacılar tarafından veya Batı'da yayınlandığına dair yaygın algının eksikliğine literatür bazında dikkat çekilmesi;

3. Tezyînî kitap sanatları (tezhip, minyatür, katı' ve cild) alanında akademik çalışmalara yeni başlayan genç araştırmacılar için kapsamlı bir Türkçe kaynakçanın oluşturulması;

4. Genel olarak genç araştırmacılar tarafından yapılan yayınlarda, özellikle de yüksek lisans ve doktora düzeyindeki tez çalışmalarında konu ve içerik itibarıyla tekrarların önüne geçilmesi.

G. Küpeli’nin çalışmasında öncelikli olarak daha önce yayınlanmış olan Türkçe bibliyografilere başvurulmuştur. Yapılan kısa tavsiften de anlaşıldığı üzere, İ. Binark, N. Atasoy, S. Bayram, M. Ağaoğlu, Ö. Çepnioğlu, Ş. Memili ve E. Kök'ün doğrudan tezyînî kitap sanatlarına odaklanan bibliyografya çalışmaları bunların başında geliyor. İlaveten, Türk-İslam sanatlarını konu alan genel bibliyografyalara veya bibliyografik eserlerin değerlendirildiği çalışmalara müracaat edilmiştir. Aynur Durukan (2007; Durukan ve Ünal,1994), Yavuz Tiryaki (2002), Aziz Doğanay (2009), Halil İbrahim Düzenli (2009) ve Ayla Ödekan (1974) tarafından yayınlanan değerli çalışmaları, söz konusu kaynaklara örnek olarak gösterilebilir. Yine bu türden yayınlar arasında Oktay Aslanapa (2004), İsmail E. Erünsal (2017), A. Esat Bozyiğit (1992) ve Sedat Bayrakal’ın (2000) yayınları, özellikle 1990 öncesi tezlerin tespiti hususunda çalışmaya büyük katkı sağlamıştır.

Farklı disiplin, dönem, kurum ve yayın türü üzerinden Türkiye'deki sanat tarihi araştırmalarına katkıda bulunan bu çalışmalar kadar, sanat tarihçileri hakkındaki yayınlar da büyük önem arzetmektedir. Bu bakımdan, genelde Türk-İslam sanatları tarihine, özelde ise klasik kitap sanatlarına dair çalışmalarıyla bilinen araştırmacılar hakkındaki bibliyografyaların, tezyînî kitap sanatlarına yönelik genel bibliyografya çalışmalarındaki iş yükünü bir nebze de olsa kolaylaştırdığı ifade edilmelidir. Türkiye'de klasik kitap sanatlarının yeniden canlandırılmasına hayatlarını adayan ve çalışmalarıyla bu alanı akademik bir disipline dönüştüren Süheyl Ünver (Mesera, Kazancıgil ve Sayar, 2017; Ergin, 1941), Uğur Derman (Akgül ve Yiğitbaş, 1996), Çiçek Derman (Akgül, 2010) Yıldız Demiriz (Altun, 2001, ss. 19-23), Semavi Eyice (Akçaoğlu ve Doğan, 2009), Emel Esin (Baykara, 1974a, ss. 30-34; 1974b, ss. 38-41), Günsel Renda (Yaman ve Bağcı, 2011, ss.13-26) ve Filiz Çağman (Mahir, 2019, ss. 27-32) gibi uzman kişilerin eserleri hakkındaki bibliyografik denemeler ilgili yayınların en önemlilerindendir. Bütün 
bunlara farklı kurumların yayınlarını içeren bibliyografyalar, dergi ve ansiklopedi indeksleri ile Nurhan Atasoy, Günsel Renda, Zeren Tanındı, Serpil Bağcı ve Banu Mahir gibi araştırmacıların ufuk açıcı eserlerinin zengin kaynakçaları da eklendiğinde (Tuncer, 2002; Çabuk, 1994; Orhan, 1974; San, 1979), söz konusu bibliyografyaya temel teşkil eden literatürün ne kadar geniş bir yelpazeye yayıldığı daha iyi anlaşılmaktadır.

Burada üzerinde durulması gereken bir diğer önemli nokta, künyelerin tespiti sırasında, bahsi geçen matbu kaynakların yanı sıra dijital katalog ve bibliyografya çalışmalarından da büyük oranda istifade edilmiş olmasıdır. Batı kaynaklı yayınlar söz konusu olduğunda, uluslararası ve ulusal ölçekte hizmet veren (OCLC WorldCat, COPAC, LIBRIS) ya da belirli bir bölge, alan ve konu temelinde oluşturulan (Index Islamicus, OhioLink, MELVYL) dijital katalog ve bibliyografyalardan faydalanmak mümkündür. Fakat Türkçe karakterler dikkate alınmadan hazırlanan bu veri tabanları, Türkçe yayınların (özellikle, makale ve bildirilerin) belirlenmesi hususunda sağlıklı bir sonuç vermediği için taramalar sırasında ulusal veri tabanlarına öncelik tanınmıştır. Türkiye Bilimsel ve Teknolojik Araştırma Kurumu Ulusal Akademik Ağ ve Bilgi Merkezi (ULAKBİM) çatısı altında geliştirilen Ulusal Toplu Katalog (TO-KAT) ve DergiPark, Yüksek Öğretim Kurulu (YÖK) Ulusal Tez Merkezi, Milli Kütüphane Türkiye Makaleler Bibliyografyası, Türkiye Diyanet Vakfı İslam Araştırmalar Merkezi (İSAM) Kütüphanesi Makaleler Veri Tabanı, Ankara Üniversitesi Dergiler Veritabanı, Hacettepe Üniversitesi Türkiye Kaynakçası söz konusu dijital veri tabanlarının en önemlilerindendir.

Matbu katalog ve bibliyografya eserlerinin zaman aşımına uğrayarak güncelliğini kaybetmesi sorununu büyük oranda ortadan kaldırabilecek bu kaynakların bibliyografya çalışmalarına büyük katkı sağladığını söylemeliyiz. Fakat ülkemizdeki dijital kataloglama çalışmalarında henüz veri bütünlüğünün sağlanamadığı, geçmiş yıllara ait yayınların titizlikle taranmadığı ve gerekli periyodik güncellemelerin sistematik olarak yapılmadı̆̆ı göz önüne alınırsa, sadece bu türden verilere dayandırılan bir bibliyografya çalışmasının eksik kalacağı muhtemeldir. Örneğin YÖK’ün Ulusal Tez Merkezi, Türkiye'de yapılan lisansüstü çalışmaların tespiti açısından önemli bir kaynak niteliği taşımasına rağmen, 1990 öncesi tezlerin belirlenmesi konusunda yetersizdir. Ulusal Toplu Katalog'da pek çok makale ve tezin yanlışlıkla kitap olarak kaydedilmesi, bilimsel yaklaşım eksikliği veya bu projenin henüz tamamlanmadığı şeklinde yorumlanabilir. Türkiye Kaynakçası'nda aynı araştırmacıya ait yayınlara bazen farklı başlıklar altında ya da eksik biçimde yer verildiği gibi, Ankara Üniversitesi Dergiler Veritabanı ve DergiPark üzerinden de ancak belirli süreli yayınlardaki makalelere ulaşılabilir.

Mevzu bahis edilen kaynakların/veri tabanlarının ışı̆̆ında şekillenen Tezyînî Kitap Sanatları Türkçe Yayınlar Bibliyografyası adlı çalışmanın literatür envanteri, Türk-İslam kitap sanatlarından benzer kompozisyon ve tasarım ilkelerine sahip dört sanat dalını (tezhip, minyatür, cild ve katı') kuşatmaktadır. Dolayısıyla söz konusu ilkeler açısından farklılık arz eden $e b r u ̂$ konusundaki çalışmalar dışarıda bırakılmıştır. Yine klasik tezyînat örnekleri hakkında önemli bilgileri muhtevî katalog tarzı yayınlar istisna olmakla hüsn-i hat çalışmaları kitaba alınmamıştır. Zira hüsn-i hat, mahiyeti gereği bir bezeme sanatı olmadığı gibi ilgili çalışmaları içeren müstakil bir bibliyografya da hazırlanmıştır (Bayat, 2002).

Tespit edilen bibliyografik künyeler; "kitaplar", "kitap bölümleri ve bildiriler", "makaleler ve ansiklopedi maddeleri”, "lisansüstü tez çalışmaları" şeklinde dörtlü bir tasnife tabi tutulduğu görülmektedir. Somut çıktıları takip edilemediği için yayınlanmamış konferans, sempozyum ve kongre bildirileri bibliyografyaya alınmamıştır. Aynı şekilde gazete yazıları, güncel sanat çalışmalarına ilişkin kataloglar, genel kütüphane katalogları ve Osmanlıca neşirler, künyelerine yer verilmeyen yayın türleri arasındadır. 
Yayın olarak kabul edilmeyen yüksek lisans ve doktora tez çalışmaları ise tezyînî kitap sanatlarımızın akademik ortamdaki seyrini belirlemeleri hasebiyle literatüre özellikle dâhil edilmiştir. Alfabetik olarak düzenlenen bibliyografik listenin sonunda araştırmacılara kolaylık sağlaması amacıyla ilgili yayını bulunan yazarların; tezhip, minyatür, cild ve katı' sanatlarına ilişkin temel kavramların; sanatçı, sanat hamisi, sanat merkezi ve kütüphanelere işaret eden özel isimlerin ve yayın kronolojisinin sıra numaralarına göre düzenlendiği dizin kısmına yer verilmiş̧tir.

Tezyînî kitap sanatları (tezhip, minyatür, katı' ve cild) alanında yapılan bibliyografyalar üzerinden bir istatistik yapacak olursak, aşağıdaki grafikten de görüleceği üzere, 1927- Haziran 2019 arasında Latin alfabesiyle hazırlanan Türkçe çalışmaların toplam sayısı tekrarlarla birlikte 2637'dir. Bunlardan 353'ü (13\%) kitap, 689'u (26\%) kitap bölümü ve bildiri, 1183'ü (45\%) makale ve ansiklopedi maddesi, 412'si ise lisansüstü tezlerden (16\%) oluşmaktadır. Makale ve ansiklopedi maddeleri kümesindeki çoğunluk makalelerin (865 künye), lisansüstü tezler kümesindeki çoğunluk ise yüksek lisans çalışmalarının (326 künye) payına düşmektedir.

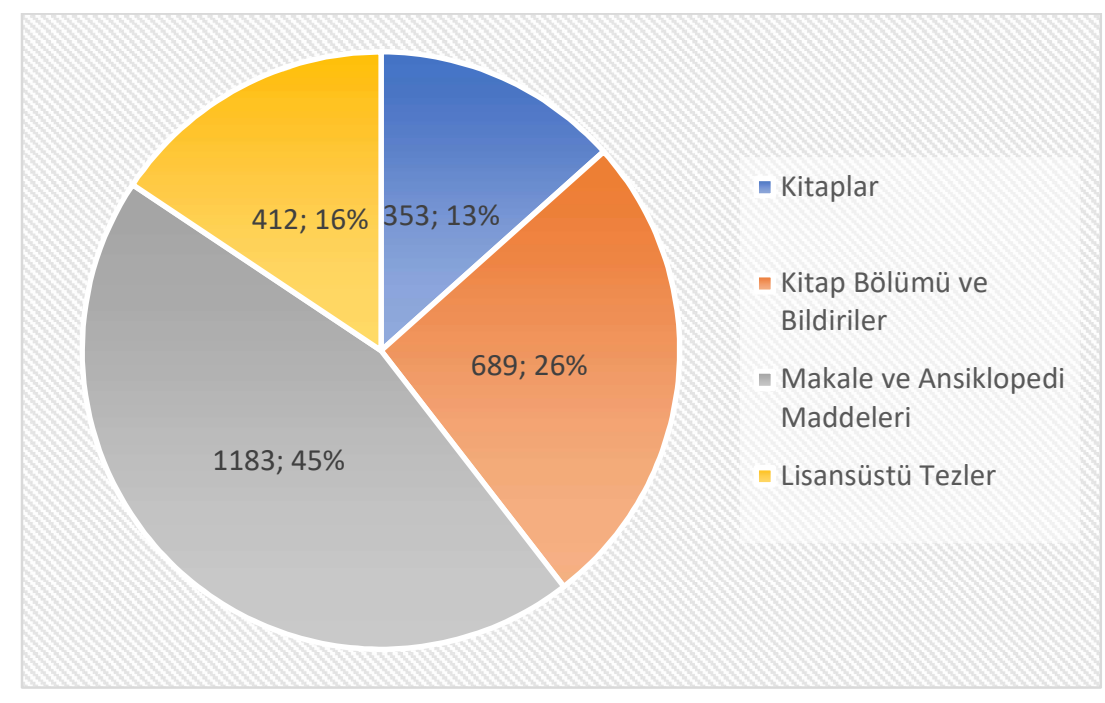

Grafik 1. Tezyînî Kitap Sanatları Konulu Türkçe Çalışmaların Format İtibarıyla Dağılımı

Takriben 90 ylllık bir zaman dilimini kuşatan bu yayınların gelişim süreci, Banu Mahir'in Kitap Sanatları Araştırmaları adlı makalesinde farklı dönemlere ve araştırmacıların ilgi alanlarına göre ana hatlarıyla değerlendirilmiştir (Mahir, 2009, ss. 209-247.) Daha açı ifade edilirse, Türkiye'de kitap sanatlarına dair sistemli araştırmaları 1924 yllına kadar geri götüren B. Mahir, 1924-2009 tarihleri arasında çeşitli alan ve disiplinlerden olan Türk bilim insanlarının minyatür, tezhip, cilt ve ebru sanatlarına yönelik araştırmalarını, muhtevalarına ve sanat tarihine olan katkılarına da değinmek suretiyle tanıtmaktadır. Makalenin yakın dönemde yayınlanmış olmasına binaen, B. Mahir'in kitap ve makale türünden yayınlara dair isabetli tespitlerini burada tekrar etmenin fuzûlî olacağı kanaatindeyiz. Bu nedenle sadece bazı önemli noktalara dikkat çekmekle yetineceğiz ki bunların büyük bir kısmı kitap tezyînatı konulu maddeleri ihtiva eden ansiklopediler ve lisansüstü tezler hakkındadır.

Türk-İslam kitap tezyînatıyla ilgili güncel bilgilerin, Türkiye'deki ansiklopediler üzerinden bütüncül bir resmini çizmek imkânsız denecek kadar zordur. Bu bir taraftan Türkiye'deki ansiklopedi çalışmalarının yeterli düzeyde olmamasından, diğer taraftan da bazı sosyo-politik nedenlerden ötürü tezyînî kitap sanatlarına dair bilgilerin mevcut çalışmalara yeterince yansıtılmamasından kaynaklanmaktadır. İlgili 
literatür çerçevesinde müracaat edilebilecek en eski yayınlar, 1940'lı yıllarda İsmail Hakkı İzmirli'nin öncülüğ̈̈nde hazırlanan İslam-Türk Ansiklopedisi, Nüzhet İslimyeli’nin 1967-1971 ylllarında neşredilen Türk Plastik Sanatçlları Ansiklopedisi, Celal Esad Arseven'in 1975 yllında vücûda getirdiği Sanat Ansiklopedisi, 1980’li ylllarda Ayvaz Gökdemir’in genel redaktörlüğünde yayınlanan Yeni Türk Ansiklopedisi ve bir çeviri projesi olarak hayata geçirilen Milli Eğitim Bakanhı̆̆ İslam Ansiklopedisi'dir. N. İslimyeli ile C.E. Arseven'in yapıtları dışarıda tutulursa, bu ansiklopedilerde tezyînî kitap sanatlarıyla ilgili maddeler oldukça sınırlıdır. Kaldı ki söz konusu iki eser de gerçek anlamda bir ansiklopedi sayılmayabilir. N. İslimyeli’nin eseri bir tür biyografik monografi tarzında kaleme alınmış olup, yazarın kendisinin de ifade ettiği gibi "Türk plastik sanatları" alanında çalışmaları bulunan kişilerin biyografilerinden oluşmaktadır. Bütün medeniyetler için değerlendirme ölçütünün kültür ve sanat olduğunu ifade eden yazar, Türk sanatçıların güzel sanatların bütün dallarında dünya sanat tarihine katkıda bulunduklarını vurgulamış ve minyatür ile hat sanatını resmin bir dalı olarak takdim edip, 70 civarında müzehhip, nakkaş, musavvir ve mücellit biyografisine yer vermiştir (İslimyeli, 1967, s.3). Böyle bir anlamlandırma girişimi, o dönemde Türk-İslam sanatlarına karşı mesafeli yaklaşıma ışık tuttuğu gibi, yazarın verdiği pek çok bilgi de teyide muhtaçtır.

Türklük vurgusu bağlamında gerçekleştirilen bu temellendirme ihtiyacının benzer yansımalarını, C. E. Arseven'in ansiklopedik sözlük tarzında ortaya koyduğu Sanat Ansiklopedisi’nde de görmek mümkündür. Türk Plastik Sanatçlları Ansiklopedisinnin aksine daha akademik bir intiba uyandıran bu çalışma, Fransızca karşılıkları verilen kavramlar ekseninde kurgulanmıştır. Sanat tarihi araştırmalarında kavram konusundaki güçlüklere değinen yazar, "geçmiş dönemlerde dünyayı hayran brrakan sanat eserleri yaratan Türkler tarafindan geliştirilen kavram ve terimlerin” zaman içinde unutulduğunu vurgulamaktadır. Ona göre söz konusu unutulma, siyasi ve ekonomik nedenler dolayısıyla sanatın ihmal edildiği dönemlerde başlamış ve "birçok eski sanatların sönmesi onlara ait terimleri de unutturmuştur.” Bazı sözlükler ise tamamen Batı kaynaklı terimlerden yola çıkılarak hazırlanmış ve geleneksel sanat terminolojimizde bunların karşılıklarının bulunduğu gerçeği göz ardı edilmiştir. Özetle, "bu meseleleri mümkün mertebe halletmek ve sanat lisanımıza bir duruluk ve dururluk vermek düşüncesiyle” yola çıkan C. E. Arseven, 1926 yılında hazırladığı Sanat Kamusu'nu yeniden tetkik ve büyütmek suretiyle Sanat Ansiklopedisi’ne dönüştürmüştür (Arseven, 1975, ss.1-7).

Ansiklopedi çalışmalarının 1990'lı yllardan itibaren klasik kitap tezyînatı konusunda nispeten daha kapsamlı bilgiler içerdiği görülmektedir. Bu yıllarda ve daha sonrasında neşredilen Eczacıbaşı Sanat Ansiklopedisi, Osmanl Ansiklopedisi ve Türkler Ansiklopedisi’ndeki maddelerin sayısı yine az olmakla birlikte içerikleri Güner İnal, Ali Alparslan, Ayla Ödekan, Oktay Aslanapa, Ahmet Saim Arıtan, Günsel Renda, Zeren Tanındı, Çiçek Derman, İnci Ayan Birol ve Banu Mahir gibi sanat araştırmacıları tarafından zenginleştirilmiştir. İlgili yayınlar arasında hem sayı hem de içerik itibarıyla en zengin materyale sahip çalışma ise hiç kuşkusuz, 1988 yılından günümüze kadar uzayan Türkiye Diyanet Vakfi İslam Ansiklopedisi'dir. Bu ansiklopediden bibliyografyaya dâhil ettiğimiz 60 küsur maddede, çoğunlukla Filiz Çağman, Zeren Tanındı, Uğur Derman, Çiçek Derman, İnci Ayan Birol ve Ali Alparslan’ın imzalarına rastlıyoruz. Aynı şekilde Nurhan Atasoy, Banu Mahir, Muhittin Serin, Selçuk Mülayim, Aziz Doğanay ve Gülnur Duran gibi araştırmacıların kavram ve şahıs üzerine yazılan maddelerine de yer verilmiştir. Olumlu yönlerine rağmen TDV İslam Ansiklopedisìnin içeriğinin tezyînî kitap sanatları konusunda yeterli düzeyde olmadığını belirtmek zorundayız. Nitekim maddeler arasında gerek Osmanlı gerekse de Timur, İlhanlı, Safevi ve Memluk dönemlerinde yaşadığı bilinen pek çok sanatkârın ismine rastlanmamaktadır. Ansiklopedi'de Levnî, Matrakçı Nasuh, Babanakkaş veya Behzâd gibi bazı meşhur sanatkârların hayatları hakkında maddeler mevcuttur. Ancak en az onlar kadar döneminde meşhur ve sultanın ihsan-ı şahanesine mazhar olmuş Nakkaş Osman, Sâdıkî, Dost 
Muhammed, Nakkaş Rûzbihân veya Behzâd ile aynı eser üzerinde imzası bulunan Yarî hakkında herhangi bir bilgi bulunmaz. Yahut tezyini kitap sanatlarının ortak dilini oluşturması açısından önemli olan ruganî, çintemani, münhanî, zerendûd, zerenderzer gibi bazı ıstılahlar henüz müstakil maddelere dönüşmemiştir.

Burada dikkat çekmenin yerinde olacağını düşündüğümüz bir diğer konu, Türkiye’de yapılan lisansüstü çalışmalarıyla ilgilidir. Bibliyografyaya dâhil ettiğimiz toplam 412 lisansüstü tezden 326'sı yüksek lisans, 86'sı ise doktora ve sanatta yeterlik düzeyinde hazırlanmıştır. Yine bu çalışmalardan 400'ü, 1989-2019 yılları arasında ve 40 farklı üniversitede tamamlanmıştır.

\begin{tabular}{|c|c|c|c|c|c|c|c|}
\hline & \multirow{2}{*}{$\begin{array}{c}\text { Çalışmanın } \\
\text { Yapıldığı Üniversite }\end{array}$} & \multicolumn{2}{|c|}{ (1989-2000) } & \multicolumn{2}{|c|}{ (2001-2010) } & \multicolumn{2}{|c|}{ (2011-2019) } \\
\hline & & $\begin{array}{l}\text { Yüksek } \\
\text { Lisans }\end{array}$ & $\begin{array}{c}\text { Doktora/Sanatta } \\
\text { Yeterlik }\end{array}$ & $\begin{array}{l}\text { Yüksek } \\
\text { Lisans }\end{array}$ & $\begin{array}{l}\text { Doktora/Sanatta } \\
\text { Yeterlik }\end{array}$ & $\begin{array}{l}\text { Yüksek } \\
\text { Lisans }\end{array}$ & $\begin{array}{c}\text { Doktora/Sanatta } \\
\text { Yeterlik }\end{array}$ \\
\hline 1. & Anadolu Ün. & 1 & & & & 1 & \\
\hline 2. & Akdeniz Ün. & & & & & & 1 \\
\hline 3. & $\begin{array}{l}\text { Ankara Hacı Bayram } \\
\text { Veli Ün. }\end{array}$ & & & & & & 1 \\
\hline 4. & Ankara Ün. & & & 3 & 1 & 1 & \\
\hline 5. & Atatürk Ün. & 3 & & 4 & 2 & 30 & 1 \\
\hline 6. & Boğaziçi Ün. & 1 & & & & & \\
\hline 7. & $\begin{array}{l}\text { Çanakkale Onsekiz } \\
\text { Mart Ün. }\end{array}$ & & & & & 1 & \\
\hline 8. & Dicle Ün. & & & 1 & & & \\
\hline 9. & Dokuz Eylül Ün. & 3 & 1 & 4 & 3 & 6 & 1 \\
\hline 10. & Dumlupinar Ün. & & & & & 1 & \\
\hline 11. & Ege Ün. & & & 3 & & & 1 \\
\hline 12. & Erciyes Ün. & & & 4 & 1 & 1 & 1 \\
\hline 13. & $\begin{array}{l}\text { Fatih Sultan Mehmet } \\
\text { Vakıf Un. }\end{array}$ & & & & & 18 & \\
\hline 14. & Firat Ün. & & & 1 & & 1 & \\
\hline 15. & Gazi Ün. & 9 & 1 & 20 & 1 & 21 & 2 \\
\hline 16. & Hacettepe Ün. & 4 & 1 & 4 & 7 & 7 & \\
\hline 17. & Haliç Ün. & & & & & 2 & \\
\hline 18. & $\begin{array}{l}\text { Hatay Mustafa Kemal } \\
\text { Ün. }\end{array}$ & & & & & 1 & \\
\hline 19. & Ișıłk Ün. & & & & & 1 & \\
\hline 20. & İstanbul Aydın Ün. & & & & & 1 & \\
\hline 21. & $\begin{array}{l}\text { İstanbul Kemerburgaz } \\
\text { Ün. }\end{array}$ & & & & & 1 & \\
\hline 22. & İstanbul Teknik Ün. & 2 & 1 & & & 3 & 1 \\
\hline 23. & İstanbul Ün. & 1 & 10 & & 1 & 3 & 2 \\
\hline 24. & $\begin{array}{l}\text { Kahramanmaraș } \\
\text { Sütçü İmam Ün. }\end{array}$ & & & & & 1 & \\
\hline 25. & Marmara Ün. & 19 & 3 & 8 & 6 & 16 & 3 \\
\hline 26. & Mersin Ün. & & & 1 & & & \\
\hline 27. & $\begin{array}{l}\text { Mimar Sinan Güzel } \\
\text { Sanatlar Ün. }\end{array}$ & 8 & 8 & 21 & 2 & 11 & 5 \\
\hline 28. & $\begin{array}{l}\text { Necmettin Erbakan } \\
\text { Ün. }\end{array}$ & & & & & 8 & \\
\hline 29. & Niğde Ün. & & & & & 1 & \\
\hline 30. & Nișantașı Ün. & & & & & 1 & \\
\hline 31. & Ondokuz Mayıs Ün. & & & & & 2 & 1 \\
\hline 32. & Pamukkale Ün. & & & & & 2 & \\
\hline 33. & Sakarya Ün. & & & 3 & & 2 & \\
\hline 34. & Selçuk Ün. & 1 & 2 & 13 & 2 & 8 & 2 \\
\hline 35. & Sivas Cumhuriyet Ün. & & & & & 1 & \\
\hline 36. & $\begin{array}{l}\text { Süleyman Demirel } \\
\text { Ün. }\end{array}$ & 1 & & 1 & & 13 & 3 \\
\hline 37. & Uludağ Ün. & & & & & 2 & \\
\hline 38. & Ușak Ün. & & & & & 3 & \\
\hline 39. & Ylldı Teknik Ün. & & & 1 & & 1 & \\
\hline 40. & Yüzüncü Y1l Ün. & 1 & & 2 & & 1 & 1 \\
\hline
\end{tabular}

Tablo 1. Tezyînî Kitap Sanatları Konulu Tez Çalışmalarının Akademik Düzey ve Üniversitelere Göre Dağılımı

Ortaya çıkan bu ilginç tablodan da anlaşlacağı üzere söz konusu çalışmaların yıllara, eğitim düzeylerine ve üniversitelere göre dağılımları bile müstakil bir araştırma konusu yapılabilir. Örneğin, Türkiye'de hazırlanan yüksek lisans ve doktora/sanatta yeterlik çalışmaları arasındaki oran, 1989-200o yılları 
arasında 54/27, 2001-2010 ylları arasında 94/26, 2011-2019 ylları arasında ise 173/26 nispetinde cereyan etmiştir. Diğer bir ifadeyle, her dönemde yüksek lisans çalışmalarında iki misline yakın bir artış yaşandığı halde, doktora çalışmalarında niceliksel bir değişim gerçekleşmemiştir. 1989-2000 yıllarına ait toplam 27 doktora/sanatta yeterlik tezinin büyük bir kısmı sırasıyla İstanbul Üniversitesi (10), Mimar Sinan Güzel Sanatlar Üniversitesi (8) ve Marmara Üniversitesi’nde (3) hazırlanmıştır. 2001-2010 ylllarında, ilk üçte Hacettepe Üniversitesi (7), Marmara Üniversitesi (6) ve Dokuz Eylül Üniversitesi (3) olmak üzere toplam 26 çalışmaya imza atılmıştır. 2011-2019 yllarında doktora/sanatta yeterlik tezlerinin toplam sayısı (26) değişmezken üniversitelere göre dağılımları değişmiş ve sayısal verilere göre Mimar Sinan Güzel Sanatlar Üniversitesi (5) birinci sıraya yükselmiştir. Yüksek lisans çalışmalarına gelince, yapılan tez çalışmalarının sayısına göre ilk üç üniversite, 1989-2000 yıllarında Marmara Üniversitesi (19), Gazi Üniversitesi (9) ve Mimar Sinan Güzel Sanatlar Üniversitesi (8); 20002010 yllarında Mimar Sinan Güzel Sanatlar Üniversitesi (21), Gazi Üniversitesi (20) ve Selçuk Üniversitesi (13); 2011-2019 yllarında ise Atatürk Üniversitesi (30), Gazi Üniversitesi (21) ve Türkiye'deki en genç yükseköğretim kurumlarından olan Fatih Sultan Mehmet Vakıf Üniversitesi (18) olmuştur.

Lisansüstü tez çalışmalarının içerikleri ile yıl, eğitim düzeyi ve üniversitelere göre dağılımları arasında çapraz karşılaştırmalı analizlerin yapılması durumunda, zaman zaman olağan dışı görünüm sergileyen istatistiksel verilerin daha iyi anlaşlabileceği kanaatindeyiz. Örneğin, son 30 ylda yüksek lisans çalışmalarındaki katlanan artışa rağmen, doktora/sanatta yeterlik tezlerinde nicelik olarak değişim yaşanmaması hangi sosyal, kültürel ve ekonomik nedenlerden kaynaklanmaktadır? Tezlerin içeriği hangi düzeydedir ve bunlar tezyînî kitap sanatlarının bütün konularını orantılı biçimde içeriyorlar mı? Tez çalışmaları ile bu çalışmalara imza atan akademisyenlerin kitap, makale ve bildiri türünden bilimsel yayınları arasındaki ilişki düz orantılı mıdır? Tezyînî kitap sanatlarıyla ilgili bilimsel yayınlarda tabir, ıstılah ve kavram bütünlüğü sağlanmış mıdır?

$\mathrm{Bu}$ ve benzeri soruları çoğaltmak mümkün olmakla birlikte, bunları ayrıntılı biçimde cevaplandırmak daha geniş bir araştırmanın konusudur. Fakat şu kadarını belirtebiliriz ki tez çalışmalarıyla ilgili en önemli problem, içlem ve kaplam sorunudur. Bir kısım tezler, klasik kitap sanatlarına ilişkin çalışmalar kümesindeki konumları iyi belirlenmediği için sağlam bir araştırma zeminine oturtulamamış; belli bir boşluğu doldurma kaygısıyla değil, popüler konuları çalışma arzusu ile kaleme alınmıştır. Birbirinin tekrarı niteliğindeki çalışmaları doğuran bu durumun tezyînî kitap sanatlarına sağladığı katkı, nitelik değil, nicelik yönündendir. Mevcut literatürden en az yarısının minyatür konusunu ihtiva etmesine karşılık, katı' sanatına dair yayınların iki elin parmaklarını geçmeyecek kadar az olmasının bir nedeni de bu olmalıdır. Aynı şekilde ilgili çalışmalarda Türk-İslam kitap sanatlarının bütün gelişim evrelerine ve problemlerine gereği kadar ışık tutulduğunu, kavram ve imla bütünlüğünün sağlandığını söylemek şimdilik zor görünmektedir. Örneğin ilgili yayınlarda "Ağa Mirek/Aga Mirek/Ağamirek/Aka Mirek”, "kat'1/katı'/kaatı'/katıa" gibi farklı imlâ tercihlerine ve "zübdet-ül tevarih", "suver’ul kevakib" şeklindeki garip/yanlış terkiplere rastlamak mümkündür.

\section{Sonuç}

Tezyînî kitap sanatları alanında 1960'ların sonundan günümüze uzanan Türkçe bibliyografya çalışmalarının 50 yıllık serüveninin üç kitap, beş makale ve bir tez çalışmasına sığdırıldığını belirtmek zorundayız. Tamamı basit bibliyografya özelliği taşıyan söz konusu çalışmalarda eserlerin içeriğine ilişkin tahlil ve tenkitlere yer verilmemektedir. Yine bazı istisnaları dikkate almazsak, bu çalışmalar genelde minyatür eksenli olup tezhip, katı' ve cild gibi diğer kitap bezeme sanatlarını en iyi ihtimalle 
kısmen içermekte; kaydedilen künyeler büyük oranda Batı dillerindeki kitap, makale ve bildirilere işaret etmektedir. Halbuki yukarıda bahsi geçen en son bibliyografyadan da görüleceği üzere, Türk/İslam kitap sanatlarıyla ilgili bütün ciddi yayınların İngilizce, Fransızca, Rusça veya Almanca gibi yabancı dillerde hazırlandığına ilişkin düşünce hatalı bir önyargının ürünüdür. Aksine Türkçe ortaya konulan pek çok araştırma, gerek bazı bezemeli yazmaların akademik câmiâya ilk kez tanıtılması gerekse de bu sanatlara ilişkin teorik arka planın oluşturulup, kavramsal içeriğin belirlenmesi hususunda Batı'daki yayınlara dahi önayak olmuştur.

Geleneğimizin ifadesi olan tezyînî kitap sanatları hakkındaki Türkçe yayın künyelerinin sistemleştirilmesi kendi başına faydalı bir uğraşıysa da bunun tamamlanmış bir iş ya da son adım olarak algılanmaması gerekir. Diğer bir ifadeyle hazırlanan bibliyografyalar, bir taraftan alanla ilgili çalışmalardaki artı ve eksi yönlerin literatür bazında belirlenmesi diğer taraftan ise tez çalışmaları da dahil olmak üzere yayınlarda konu ve içerik itibarıyla tekrarların önüne geçilmesi için birer kıstas ve başlangıç noktasıdır. Bu noktadan hareketle geliştirilecek disiplinlerarası çapraz analizler, kitap sanatlarına dair Türkçe çalışmaları nitelik ve nicelik olarak zenginleştirecektir.

\section{Kaynakça}

Ağaoğlu, M. ve Çepnioğlu, Ö. (2015). Osmanlı Minyatür Sanatı Bibliyografyası II, Tarih ve Uygarlk İstanbul Dergisi, 7, 95-104.

Ağaoğlu, M. ve Çepnioğlu, Ö. (2014). Osmanlı Minyatür Sanatı Bibliyografyası I, Tarih ve Uygarlık Ístanbul Dergisi, 6, 165-174.

Altun, A. (2001). Yıldız Demiriz Kaynakçası, Arkeoloji ve Sanat Tarihi Araştırmaları: Yıldız Demiriz’e Armağan, B. Tanman, U. Tükel (yay. haz.). İstanbul: Simurg, 19-23.

Akçaoğlu, Y.ve Doğan, S.( 2009). Semavi Eyice Kaynakçası (86 Yıla Armağan). İstanbul: Kitap.

Akgül, M. ve Yiğitbaş, A. K. (1996). Uğur Derman Bibliyografyası. İstanbul: Türk Kütüphaneciler Derneği.

Akgül, M. (2010). Çiçek Derman Bibliyografyası. İstanbul: MTV.

Archibald, K. ve Creswell, C.( 1953). A Bibliyography of Painting in Islam. Kahire: Imprimerie de l'Institut Français D'archéologie Orientale.

Archibald, K. ve Creswell, C.(1974). A Bibliography of the Architecture, Arts And Crafts of Islam. Vaduz: Quarto Press.

Arseven, C. E. (1975). Sanat Ansiklopedisi. Ankara: Milli Eğitim Bakanlığı, 1, 1-7.

Aslanapa, O.( 2004). İstanbul Üniversitesi Edebiyat Fakültesi Tezleri (1920-1946). İstanbul: İslam Tarih, Sanat ve Kültürünü Araştırma Vakfı (İSAR).

Atasoy, N. (1972). Türk Minyatür Sanatı Bibliyografyası. İstanbul: Yapı ve Kredi Bankası.

Bayat, A. H. (2002). Açıklamalı Hüsn-i Hat Bibliyografyası. İstanbul: İslam Tarih, Sanat ve Kültür Araştırma Merkezi (IRCICA).

Baykara, T. (1974a ). Dr. Emel Esin ve Eserleri, Türk Edebiyat, 3(35), 30-34.

Baykara, T. (1974b ). Emel Esin Bibliyografyası, Türk Edebiyatı, 3(36), 38-41.

Bayram, S. (1994). Türk Hat, Yazı-Resim, Cilt, Tezhip ve Minyatür Sanatı ile İlgili Seçilmiş Bibliyografya. Vakıflar Dergisi, 23, 321-342.

Bayrakal, S. (2000). Ege Üniversitesi Edebiyat Fakültesi Sanat Tarihi Bölümü’nde 1985-1999 Yılları Arasında Yapilan Lisans, Yüksek Lisans ve Doktora Tezleri. Sanat Tarihi Dergisi [Arkeoloji ve Sanat Tarihi Dergisi], 10, 11-20. 
Binark, İ. (1969). Türk Vakıfları, Türk Sanatı ve İçtimaî Hayatı Konusu ile İlgili Eserlerin Bibliyografyası, Vakıflar Dergisi, 8, 357-366.

Binark, İ. (1973). Türk Dekoratif ve Resim, Seramik Örme ve İşleme, Heykeltraşlık, Oymacllık Meskükât ve Maden Sanatları Bibliyografyası (Kitaplar 1928-1971/Makaleler 1952-1971), Vakıflar Dergisi, $10,463-478$.

Bozyiğit, A. E.( 1992). Üniversitelerde Yapılan El Sanatları Konulu Tezler Bibliyografyası. Ankara: Kültür Bakanlığı.

Çabuk, V.( 1994). İslam Ansiklopedisi İndeksi. Ankara: Türk Tarih Kurumu.

Durukan, A. (2007) Anadolu Selçuklu Sanatı Bibliyografyası II (1993-2005). Ankara: Atatürk Kültür Merkezi.

Durukan, A. Mehlika Sultan Ünal. (1994). Anadolu Selçuklu Dönemi Sanatı Bibliyografyası. Ankara: Atatürk Kültür Merkezi.

Düzenli, H. İ.( (2009). Armağan Kitaplar: Sanat Tarihi, Mimarlık Tarihi ve Arkeolojinin Buluşma Mekanları. Türkiye Araştırmaları Literatür Dergisi [Sanat Tarihi Sayısı], 7(14), 643-656.

Doğanay, A. (2009). Sanat Tarihi Bibliyografyaları. Türkiye Araştırmaları Literatür Dergisi, 7(14), 541557.

Ergin. O. N. (1941). Prof. Dr. A. Süheyl Ünver Bibliyografyası 1381/1961. İstanbul: İstanbul Üniversitesi Tıp Tarihi Enstitüsü.

Erünsal , İ. E. v.dğr. (2017). İlahiyat Fakülteleri Tezler Kataloğu (1953-2015). Ankara: Türkiye Diyanet Vakfi.

İslimyeli, N. (1967). Türk Plastik Sanatçıları Ansiklopedisi. Ankara: Ankara Sanat, 1. 3.

Kök, E. ( 2016). Türk ve İslâm Sanatı Minyatür Bibliyografyası, İstanbul: Pendik Belediyesi.

Mahir, B. (2019). Filiz Çağman Bibliyografyası. Filiz Çağman’a Armağan. Ayşe Erdoğdu, Zeynep Atbaş, Aysel Çötelioğlu (Ed.). İstanbul: Lale, 27-32.

Mahir, B. (2009). Kitap Sanatları Araştırmaları, Türkiye Araştırmaları Literatür Dergisi [Sanat Tarihi Sayısl], 7(14), 209-247.

Memili, S.. (2007). Türk Kitap Sanatları Bibliyografyası. (yüksek lisans tezi). Gazi Üniversitesi Eğitim Bilimleri Enstitüsü: Ankara.

Mesara, G. ve Kazancıgil, A. (2017). A. G. Sayar. A. Süheyl Ünver Bibliyografyasl, İstanbul: İşaret.

Orhan, G. (1974). İstanbul Üniversitesi Edebiyat Fakültesi Yayınlar Bibliyografyası: 1924-1972. İstanbul: İstanbul Üniversitesi Edebiyat Fakültesi.

Ödekan, A.( 1974). Türkiye'de 50 Yılda Yayımlanmış Arkeoloji, Sanat Tarihi ve Mimarlı Tarihi ile İlgili Yayınlar Bibliyografyası (1923/1973). İstanbul: İ.T.Ü. Mimarlık Fakültesi.

San, A. (1979). İstanbul Üniversitesi Edebiyat Fakültesi Yayınları Bibliyografyası: 1973-1978. İstanbul: İstanbul Üniversitesi Edebiyat Fakültesi.

Sinclair, S. (2012). Bibliography of Art And Architecture in The Islamic World. (Ed.). Leiden: E.J. Brill.

Tiryaki, Y. (2002). Türkiye'de Yayınlanmış Türk ve İslam Sanatı Makaleler Bibliyografyası: I Yarı Periyodikler 1943-1997. İstanbul: Gözen.

Tuncer, H. (2002). Doksanincı Yllında Türk Yurdu (1911-2001) Bibliyografyası. Ankara: Kültür Bakanlığı.

Yaman, Z. Y. ve Bağcı, S. (2011). Günsel Renda: Kısa Özgeçmiş ve Yayınlar. Gelenek Kimlik Bireşim: Kültürel Kesişmeler ve Sanat: Günsel Renda'ya Armağan. (Yay. haz.). Ankara: Hacettepe Üniversitesi Edebiyat Fakültesi Sanat Tarihi Bölümü, 13-26. 